\title{
DAMAGE CAUSED BY THE EUROPEAN BEAVER (CASTOR FIBER L.) IN AGRICULTURAL AND FOREST FARMS IN VIEW OF SELECTED ATMOSPHERIC FACTORS AND ANIMAL BEHAVIOR
}

\author{
JANISZEWSKI, P. ${ }^{*}$ - HERMANOWSKA, Z. \\ Department of Fur-Bearing Animal Breeding and Game Management, Faculty of Animal \\ Bioengineering, University of Warmia and Mazury in Olsztyn, Oczapowskiego 5, 10-719 \\ Olsztyn, Poland \\ *Corresponding author \\ e-mail: janisz@uwm.edu.pl; Tel.: +48-89-523-4442,ORCID: 0000-0003-4654-7805 \\ (Received 20 $0^{\text {th }}$ Aug 2019; accepted 14 ${ }^{\text {th }}$ Nov 2019)
}

\begin{abstract}
The aim of this study was to track and characterize damage caused by the European beaver in private farms in the Region of Warmia and Mazury (NE Poland) in 2009-2016. The influence of selected atmospheric factors and beaver behaviour aspects on the number of compensation claims was also analyzed. The majority of damages resulting from beavers' negative impact on the human economy were related to the flooding of grasslands. The second and third most prevalent types of damage were tree cutting and flooding of tree stands, respectively. Most losses were reported in spring and summer months, which suggest that preventive measures should be undertaken mainly during that period. There were no significant relationships between the number of filed claims, temperature and precipitation levels in the analyzed years.
\end{abstract}

Keywords: Castor fiber, population increasing, beaver damage, forests, arable areas, flooding

\section{Introduction}

Beavers exert a positive influence on their occupied ecosystems, reflected in increasing biodiversity. However, beaver activity can also have negative implications for private agricultural and forest farms (Derwich and Mróz, 2008; Janiszewski et al., 2014). Beavers can substantially modify the structure of forests by foraging on the preferred tree species, which can lead to the devastation of valuable tree stands (Ciechanowski, 2010; Janiszewski and Hanzal, 2015; Tajchman et al., 2018). Beaver activity can directly or indirectly contribute to landslides and local floods. Rational management of local beaver populations poses a challenge due to the animals' unique lifestyle as well as the fact that beavers often inhabit hard-to-reach biotopes. The prevalence of active family groups is difficult to determine, and attempts to control the beaver population through harvest or hunting may be impossible or ineffective (Janiszewski et al., 2007; Janiszewski and Misiukiewicz, 2012; Januszewicz et al., 2018). Estimates of the damage caused by beavers in private farms based on the filed damage claims provide reliable information on beaver activity.

The aim of this study was to track and characterize the damage caused by the European beaver Castor fiber in private farms in the North-Eastern Poland (Region of Warmia and Mazury) in 2009-2016 in view of selected atmospheric factors and animal behavior.

\section{Materials and methods}

The study relied on data from the estimation of losses sustained due to the activity of the European beaver Castor fiber in the Region of Warmia and Mazury (NE Poland) in 
2009-2016 (Fig. 1). The relevant data was obtained from the Regional Directorate for Environmental Protection in Olsztyn $\left(20^{\circ} 30^{\prime} \mathrm{E} ; 53^{\circ} 47^{\prime} \mathrm{N}\right)$. Damage claims contained the following information:

- Date of loss

- Type of damage

The effects of the following atmospheric factors on the number of damage claims were analyzed:

- Total annual precipitation

- Mean annual temperature

- Mean temperature between March and November

Data on total annual precipitation were obtained from the Regional Inspectorate of Environmental Protection (2018), and temperature data were acquired from Statistics Poland (Statistics of Poland, 2010-2017).

In view of the legal regulations in force (Journal of Laws 2017, item 142, as amended), losses caused by beavers on private land constitute the liability of the State Treasury represented by the Regional Director of Environmental Protection.

The Region of Warmia and Mazury spans an area of $24,173.47 \mathrm{~km}^{2}$, and it accounts for $7.7 \%$ of Poland's territory. Forest cover in the region was estimated at $3.12 \%$ at the end of 2015 (Statistics of Poland, 2017).

The results were processed in Microsoft Excel 2013 and presented in tabular and graphic forms with an indication of absolute values and percentages. The coefficients of linear correlation between the total number of damage claims, flood damage claims and the analyzed atmospheric factors were calculated in Statistica 12 PL.

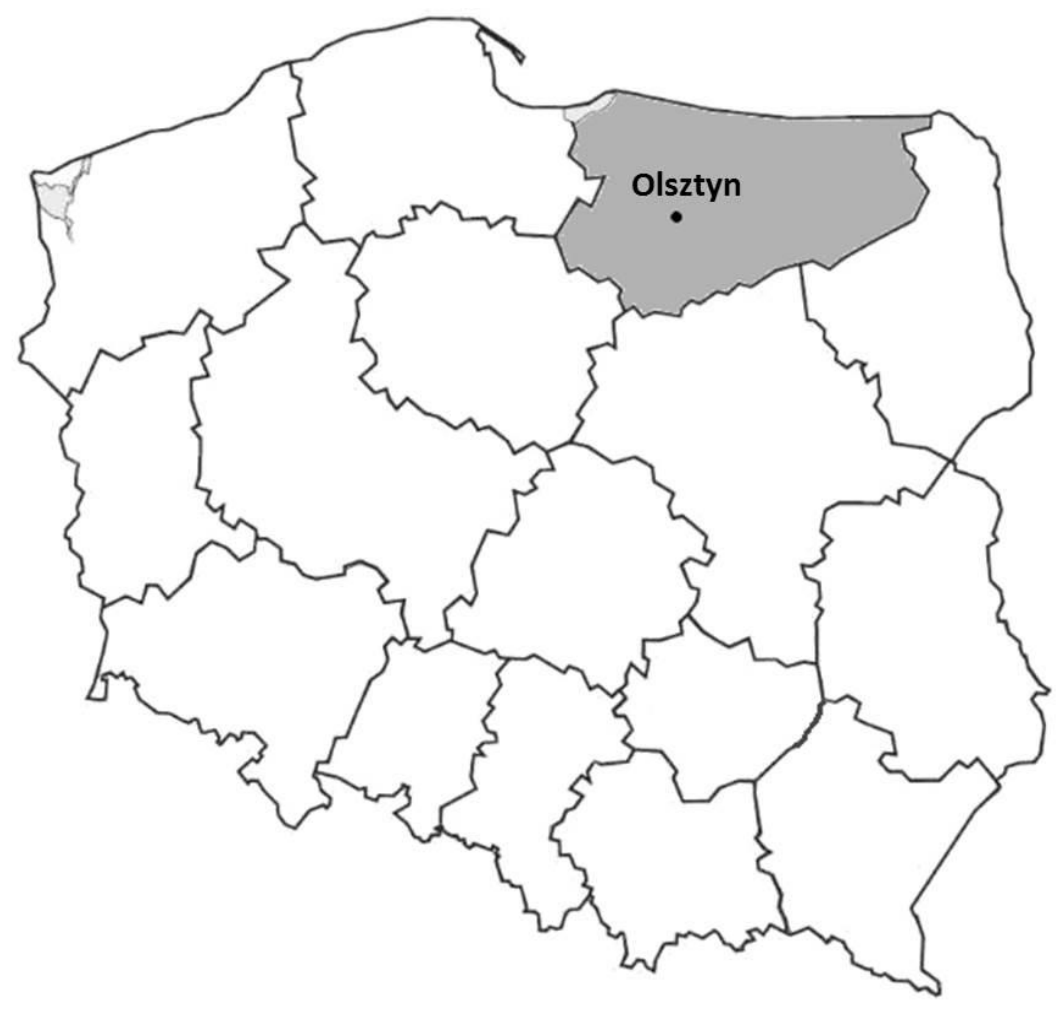

Figure 1. Research area localization 


\section{Results}

The number and type of beaver damage reported each year during the analyzed period were evaluated. The results are presented in Table 1.

Table 1. Number of complaints describing various types of beaver damage in each year of the study [number/\%]

\begin{tabular}{c|c|c|c|c|c|c|c|c|c}
\hline \multirow{2}{*}{ Type of damage } & & \multicolumn{10}{|c}{ Year } \\
\cline { 3 - 10 } & & $\mathbf{2 0 0 9}$ & $\mathbf{2 0 1 0}$ & $\mathbf{2 0 1 1}$ & $\mathbf{2 0 1 2}$ & $\mathbf{2 0 1 3}$ & $\mathbf{2 0 1 4}$ & $\mathbf{2 0 1 5}$ & $\mathbf{2 0 1 6}$ \\
\hline \multirow{2}{*}{ Grasslands - flooding } & {$[$ number] } & 425 & 549 & 660 & 775 & 863 & 855 & 755 & 738 \\
& {$[\%]$} & 66.41 & 61.96 & 51.68 & 50.85 & 47.76 & 55.74 & 51.54 & 48.49 \\
\hline \multirow{2}{*}{ Crops - flooding } & {$[$ number] } & 6 & 17 & 23 & 28 & 31 & 53 & 37 & 77 \\
& {$[\%]$} & 0.93 & 1.92 & 1.80 & 1.84 & 1.72 & 3.45 & 2.53 & 5.06 \\
\hline \multirow{2}{*}{ Tree stands - flooding } & {$[$ number] } & 9 & 46 & 160 & 349 & 442 & 64 & 74 & 206 \\
& {$[\%]$} & 1.41 & 5.19 & 12.53 & 22.90 & 24.46 & 4.17 & 5.05 & 13.54 \\
\hline \multirow{2}{*}{ Tree stands - cutting } & {$[$ number] } & 180 & 253 & 406 & 350 & 430 & 503 & 509 & 396 \\
& {$[\%]$} & 28.12 & 28.57 & 31.79 & 22.97 & 23.80 & 32.79 & 34.74 & 26.02 \\
\hline \multirow{2}{*}{ Garden crops - cutting } & {$[$ number] } & 5 & 8 & 9 & 5 & 12 & 20 & 18 & 39 \\
& {$[\%]$} & 0.78 & 0.90 & 0.70 & 0.33 & 0.66 & 1.30 & 1.23 & 2.56 \\
\hline \multirow{2}{*}{ Crops - foraging } & {$[$ number] } & 1 & 1 & 0 & 0 & 0 & 0 & 0 & 1 \\
& {$[\%]$} & 0.16 & 0.11 & 0 & 0 & 0 & 0 & 0 & 0.06 \\
\hline \multirow{2}{*}{ Fish ponds - weir } & {$[$ number] } & 11 & 8 & 8 & 4 & 8 & 22 & 46 & 14 \\
damage & {$[\%]$} & 1.72 & 0.90 & 0.64 & 0.26 & 0.44 & 1.43 & 3.14 & 0.92 \\
\hline \multirow{2}{*}{ Hydraulic structures } & {$[$ number] } & 0 & 0 & 1 & 8 & 9 & 1 & 0 & 0 \\
& {$[\%]$} & 0 & 0 & 0.08 & 0.52 & 0.50 & 0.07 & 0 & 0 \\
\hline \multirow{2}{*}{ Livestock } & {$[$ number] } & 0 & 0 & 1 & 0 & 0 & 3 & 0 & 0 \\
& {$[\%]$} & 0 & 0 & 0.08 & 0 & 0 & 0.20 & 0 & 0 \\
\hline \multirow{2}{*}{ Apiaries } & {$[$ number] } & 0 & 0 & 0 & 0 & 0 & 1 & 2 & 1 \\
& {$[\%]$} & 0 & 0 & 0 & 0 & 0 & 0.07 & 0.14 & 0.06 \\
\hline \multirow{2}{*}{ Other } & {$[$ number] } & 3 & 4 & 9 & 5 & 12 & 12 & 24 & 50 \\
& {$[\%]$} & 0.47 & 0.45 & 0.70 & 0.33 & 0.66 & 0.78 & 1.63 & 3.29 \\
\hline \multirow{2}{*}{ Total } & {$[$ number] } & $\mathbf{6 4 0}$ & $\mathbf{8 8 6}$ & $\mathbf{1 2 7 7}$ & $\mathbf{1 5 2 4}$ & $\mathbf{1 8 0 7}$ & $\mathbf{1 5 3 4}$ & $\mathbf{1 4 6 5}$ & $\mathbf{1 5 2 2}$ \\
& {$[\%]$} & $\mathbf{1 0 0}$ & $\mathbf{1 0 0}$ & $\mathbf{1 0 0}$ & $\mathbf{1 0 0}$ & $\mathbf{1 0 0}$ & $\mathbf{1 0 0}$ & $\mathbf{1 0 0}$ & $\mathbf{1 0 0}$ \\
\hline
\end{tabular}

The number of beaver damage complaints continued to increase in the first years of the analyzed period from 640 in 2009 to 1807 in 2013. These observations could point to a higher prevalence of beaver damage in the evaluated region (due to migration and/or population growth) or growing levels of awareness about financial compensation options among land owners. A minor decrease in the number of claims was noted in the following two years of the examined period (2014-2016), which could testify to the effectiveness of the implemented protective measures (such as the construction of overflow channels in beaver dams). However, the total number of compensation claims was considerably higher than in the first years of the studied period.

An analysis of the proportions of various types of damage during the studied period indicates that nearly $53 \%$ of the submitted compensation claims involved flooding and inundation of grasslands (meadows and pastures) (Fig. 2). More than $40 \%$ of the reported losses were sustained in private forests and coppices, including tree cutting $(28.41 \%)$ and flooding of tree stands $(12.67 \%)$. The relevant losses were least 
frequently sustained in crops $(0.03 \%)$. However, damage due to floods in grasslands, arable land and private forests accounted for $68 \%$ of all damages caused by beavers in the studied region.
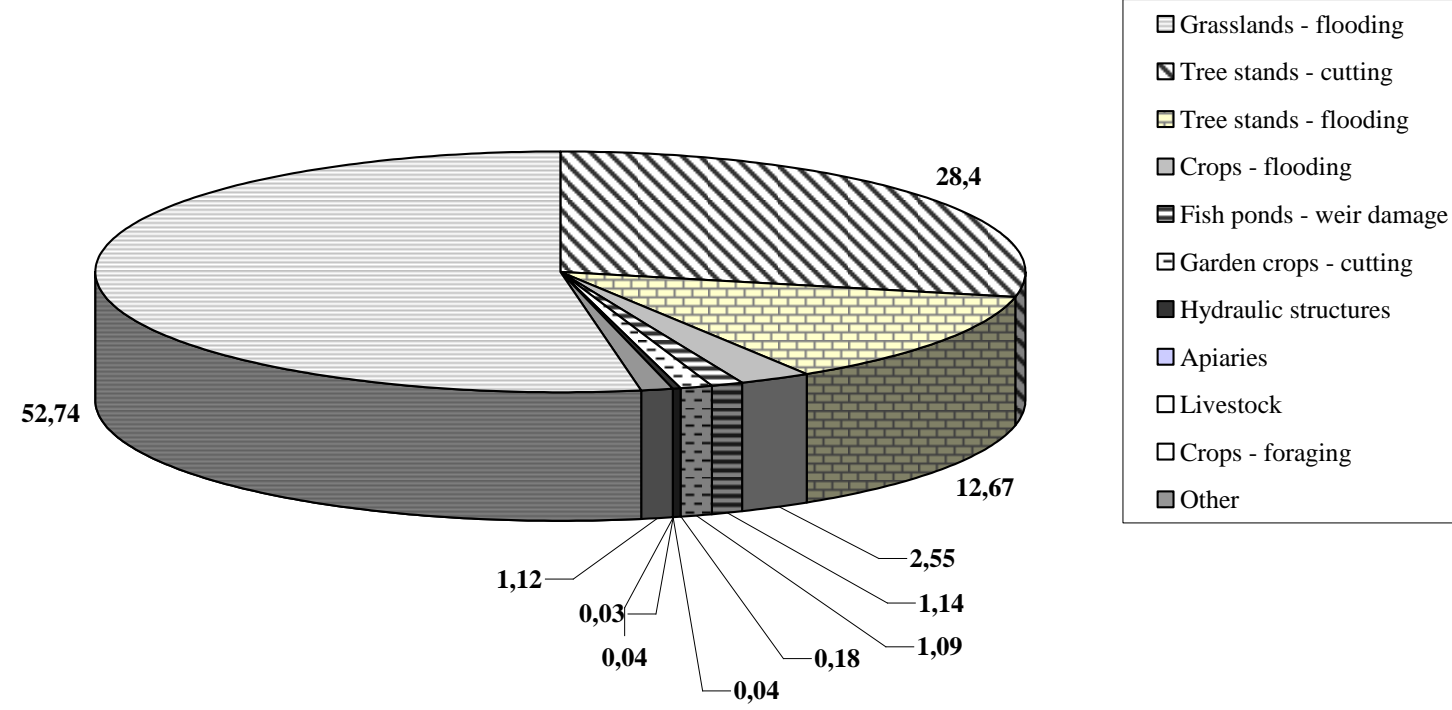

Figure 2. Different types of damage caused by beavers in 2009-2016

The number of compensation claims differed across months. The distribution (\%) of beaver damage in each month of the year is presented in Figure 3.

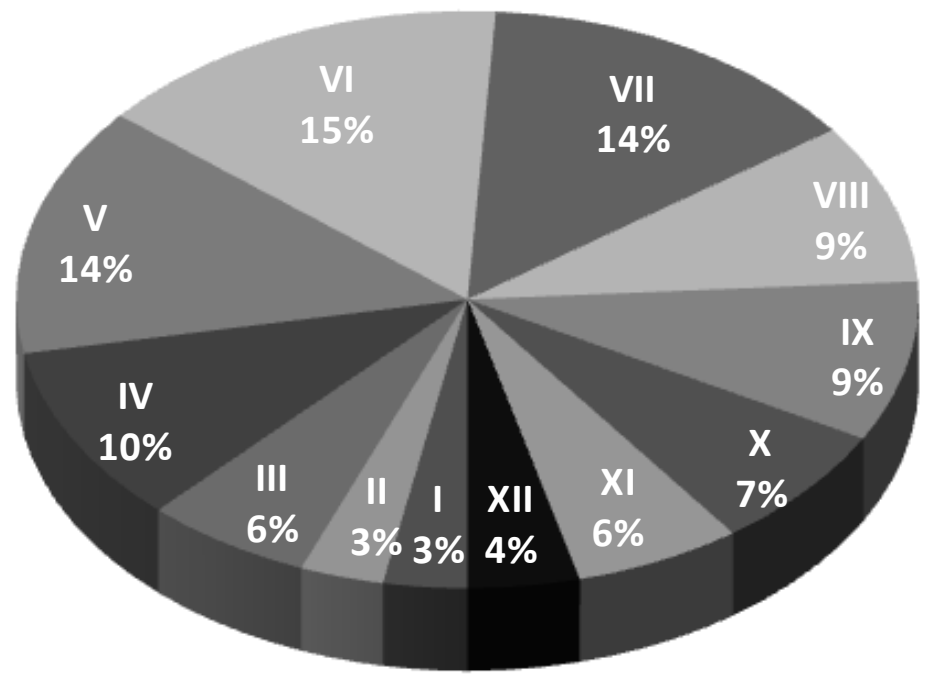

Figure 3. Distribution (\%) of reported damage caused by beavers in each month of the year

The highest number of damage claims was noted in late spring and in summer: May (14\%), June (15\%) and July (14\%), followed by April (10\%), August (9\%) and September (9\%).

Precipitation and temperature data (Table 2) and the correlations between selected atmospheric factors that could potentially influence the severity of beaver damage and the number of compensation claims in each year were analyzed (Table 3; Fig. 4). 


$$
-15637 \text { - }
$$

Table 2. Total annual precipitation $[\mathrm{mm}]$, mean air temperature $\left[{ }^{\circ} \mathrm{C}\right]$ and the number of damage claims [number] in the analyzed area

\begin{tabular}{c|c|c|c|c|c|c|c|c}
\hline \multirow{2}{*}{ Specification } & \multicolumn{7}{|c}{ Year } \\
\cline { 2 - 9 } & $\mathbf{2 0 0 9}$ & $\mathbf{2 0 1 0}$ & $\mathbf{2 0 1 1}$ & $\mathbf{2 0 1 2}$ & $\mathbf{2 0 1 3}$ & $\mathbf{2 0 1 4}$ & $\mathbf{2 0 1 5}$ & $\mathbf{2 0 1 6}$ \\
\hline $\begin{array}{c}\text { Total annual } \\
\text { precipitation }\end{array}$ & 614.8 & 750.0 & 588.4 & 685.3 & 616.8 & 493.3 & 550.2 & 727.6 \\
\hline $\begin{array}{c}\text { Mean annual } \\
\text { temperature }\end{array}$ & 7.7 & 6.7 & 8.2 & 7.5 & 7.8 & 8.9 & 9 & 8.6 \\
\hline $\begin{array}{c}\text { Temperature } \\
\text { March-November) }\end{array}$ & 11 & 11 & 11.5 & 11.4 & 10.8 & 12.2 & 11.5 & 11.4 \\
\hline $\begin{array}{c}\text { Total number of } \\
\text { damage claims }\end{array}$ & 640 & 886 & 1277 & 1524 & 1807 & 1534 & 1465 & 1522 \\
\hline $\begin{array}{c}\text { Number of flood } \\
\text { damage claims }\end{array}$ & 440 & 312 & 843 & 1152 & 1336 & 972 & 866 & 1021 \\
\hline
\end{tabular}

Table 3. Coefficients of correlation between the number of damage claims and selected atmospheric factors

\begin{tabular}{c|c|c|c|c}
\hline Parameter & $\begin{array}{c}\text { Total } \\
\text { precipitation }\end{array}$ & $\begin{array}{c}\text { Annual } \\
\text { temperature }\end{array}$ & $\begin{array}{c}\text { Temperature } \\
\text { March-November }\end{array}$ & $\begin{array}{c}\text { Total number of } \\
\text { damage claims }\end{array}$ \\
\hline Total precipitation & & & & \\
\hline Annual temperature & -0.684 & & & \\
\hline Temperature - March-November & -0.584 & 0.683 & & \\
\hline Total number of damage claims & -0.236 & 0.482 & 0.290 & \\
\hline Number of flood damage claims & -0.230 & 0.423 & 0.185 & $0.941^{*}$ \\
\hline
\end{tabular}

$* \mathrm{P} \leq 0.05$

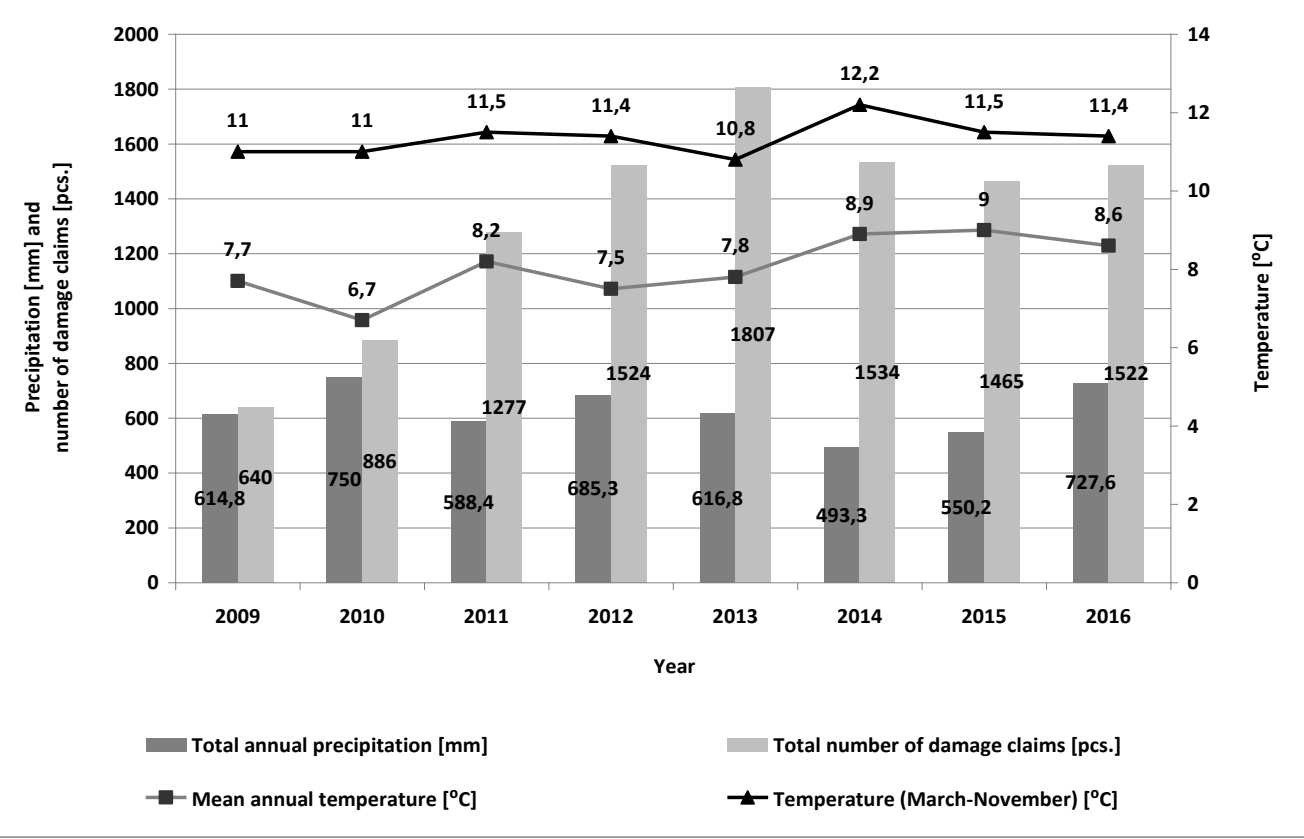

Figure 4. Number of damage claims vs. temperature and precipitation in the analyzed period 
The coefficients of correlation between the total number of damage claims, the number of flood damage claims and selected atmospheric factors were calculated. The results are presented in Table 3.

An analysis of the above data (Tables 2 and 3; Fig. 4) indicates that special attention should be paid to the correlations between annual temperature, the total number of damage claims and the number of flood damage claims. These relationships were not statistically significant, but the above variables were bound by positive correlations, and the correlation coefficient exceeded 0.4. The above implies that higher temperature intensifies beaver activity and prompts these animals to build more dams which raise water levels in rivers and increase the risk of flooding on arable land and in forests. Total precipitation and the number of compensation claims were bound by a negative correlation (-0.23), which suggests that higher precipitation discourages beavers from building dams and minimizes flooding in areas directly adjacent to watercourses.

\section{Discussion}

The severity of damage caused by beavers has not been analyzed in detail often in relevant literature (Reynolds, 2000). Various types of beaver damage were evaluated by Brzuski and Kulczycka (1999) based on the compensation claims filed in 1995-1997 in the former Polish voivodeships (before the reform of Poland's administrative division system). A total of 790 claims describing different types of damage caused by beavers had been filed in Poland in the analyzed period. The total amount of compensation payments for damage caused by beavers reached the equivalent of USD 141,000. According to the cited authors (Brzuski and Kulczycka, 1999), field and grassland floods accounted for $30 \%$ of all reported damages. In our study, flooding was the most common cause of the reported losses, but the prevalence of flood-related damage in the Region of Warmia and Mazury was higher at around 50\% (from $47.76 \%$ to $66.41 \%$ ) (Table 1; Fig. 2). A comparison of our findings with the cited results points to a rapid increase in the population size of beavers in north-eastern Poland, which is associated with a higher incidence of damage caused by beavers and, consequently, an increase in the amount of compensation payments.

Various types and extent of damage caused by beavers were also investigated in 2002-2003 by Czech (2010). In his study, the destruction of flood embankments and pond levees by burrowing beavers was the most prevalent type of damage, followed by farm flooding. In a study by Derwich et al. (2007), the most severe losses associated with beaver activity in the region of Podkarpacie (South-Eastern Poland) also included damage to flood embankments and tree stands.

Different results were noted by Wajdzik et al. (2013) who reported a total of 262 beaver damage, complaints totaling PLN 150,000 in the Region of Małopolska (South Poland). In their study, the most extensive losses (120 compensation claims) were observed in forests where beavers felled more than 14,000 of trees with a combined volume of $752 \mathrm{~m}^{3}$. The most affected tree species were willows (5850), poplars (3550), alders (2100) and oaks (1500). Beavers had a preference for trees whose diameter at breast height did not exceed $11 \mathrm{~cm}$. A total of 116 damage claims were filed by farms where beavers damaged mostly root and tuber crops (beets, carrots, parsnips) and cereals (maize, wheat). Flooding and seasonal inundation of meadows and pastures were also prevalent on agricultural land. The predominant types of losses in fish ponds included burrowing and weakening of levees, blockage of culverts, and restricted water 
flow in ditches. Kłoskowski (2011) conducted a detailed analysis of damage caused by beavers in fish farms. Severe losses were reported in $21.2 \%$ and moderate losses - in $46 \%$ of the 110 surveyed fish farms in eastern Poland. Fish ponds were not affected by beaver activity in $32.8 \%$ of the examined cases.

The expansion of the existing and potential beaver populations after reintroduction can have serious financial consequences if beaver colonies private forest and agricultural area. The relevant risks can be minimized through monitoring, which is not easily accomplished with regard to beavers, partly because of difficulties in determining the exact number of beaver colonies (Januszewicz et al., 2018). Campbell-Palmer et al. (2015) estimated the costs associated with the payment of compensation for damages caused by beavers. In Denmark, where the first beaver reintroduction scheme was introduced only in 1999, equipment costs range from EUR 1000 to 3000 per year, the cost of field staff dealing with beaver conflicts was estimated at EUR 50,000 per year, whereas EUR 40,000 is additionally spent on monitoring. In the Czech Republic which has a stable beaver population, more than EUR 2.8 million has been paid in state compensation for damages to crops and forestry in the last 15 years (average of EUR 187,000 per year). In Bavaria, voluntary state compensation for beaver damage is estimated at EUR 450,000 per year, and around 1000 beavers are now culled annually. However, while the costs associated with the mitigation of human-beaver conflicts and the payment of compensations can be estimated, the potential benefits of beavers are much more difficult to determine.

Road damages caused by beaver (Castor canadensis) were a costly problem for transportation department in the U.S. Population control and dam destruction were the most widely used methods to reduce conflicts but benefits of such measures in some situations were often very short-term (Boyles and Savitsky, 2008). To determine the potential benefits of using flow devices were installed 40 devices in 21 sites. It was important, that the costs to install and maintain the devices were significantly lower than preventative road maintenance, damage repairs, and/or population control costs.

Similar results were obtained in the territory of Alberta, Canada (Hood et al., 2018). There were 12 pond levelers devices installed to prevent flooding by Castor nanadensis and the Authors developed a cost-benefit analysis for these areas. It was found that one of the devices required constant maintenance and modification during 3 years, while the other devices required almost no maintenance. Based on a "willingness-to-pay" (WTP) of $0 \$$ and discount rate of $3 \%$ was found that installing pond levelers resulted in a present value net benefit of $81519 \$$ over 3 years and $179440 \$$ over 7 years. Scenarios incorporating discount rates of $3 \%$ and $7 \%$, horizons of either 3 or 7 years, and varying WTPs resulted in significant net benefits. Hood et al. (2018) also found that provincially, municipalities employed up to seven different methods to control damages caused by beavers, but the most commonly were: lethal control and dam removal. Total annual costs provided by 48 municipalities and 4 provincial parks districts were $3,139,223 \$$.

Czyżowski et al. (2009) compared the extent of damage to tree stands caused by beavers based on the species' foraging preferences in urban and protected areas. They found that unlike in protected areas, beavers did not have clear preferences regarding tree species and tree diameter in urban areas.

Janiszewski and Misiukiewicz (2012) analyzed the compensation claims submitted to Regional Directorates for Environmental Protection across Poland in 2009. The incidence of beaver damage was highest in the Region of Podlasie and the Region of 
Warmia and Mazury, and it was lowest in the Region of Silesia. Grassland flooding was the most prevalent type of beaver damage which was reported in $69.72 \%$ of the examined cases. The number of approved compensation claims was twice lower in the Region of Warmia and Mazury than in the Region of Podlasie, but the amount of paid compensation was highly similar in both regions. In the cited study, the following types of damage were most prevalent: flooding of meadows and pastures $(30.4 \%)$, damage to embankments and levees in fish ponds (20.12\%), tree damage (19.28\%) and losses sustained in horticulture (18.04\%).

The distribution of beaver-induced losses in different months of the year can be influenced by the biological characteristics of the species as well as the annual cycle of agricultural and forestry operations. The number of damage claims was highest in the months when many field operations are performed, in particular on grasslands which are most susceptible to beaver damage (Table 1). The summer months are also a season of beaver migration (Janiszewski et al., 2014). Offsprings are typically born in May and June which is also a period during which other members of beaver family groups temporarily leave their habitats, and individuals who attain sexual maturity (at around 3 years of age) migrate in search of mating partners and new habitats (Hartman 1997). Annual migration patterns and behaviors can also contribute to the severity of damage because migrating beavers build dams in new locations and cause floods in areas adjacent to rivers and water bodies (Gorshkov and Gorshkov, 2011).

The number of damage claims was lower in October and November (Fig. 2), which is not correlated with beaver activity, but could be linked with a small number of field operations (mainly in grasslands). However, tree cutting and felling can be intensified in autumn when beavers attempt to harvest sufficient amounts of material for reinforcing dams or accumulate food reserves before winter (Hartman, 1997; Janiszewski and Hanzal, 2015).

Janiszewski and Misiukiewicz (2012) analyzed the factors that affect the extent and type of damage caused by beavers. In addition to the size and density of beaver populations, the type and severity of the inflicted losses were directly associated with the proportion of arable land and private forests in the studied area. The area of agricultural land intersected by large rivers is one of the key factors that determine the type and extent of beaver damage. These areas are readily colonized by migrating beavers.

Tajchman et al. (2018) reported interesting findings in a study evaluating beaver damage to tree stands. The number of damaged trees was bound by a negative and nonsignificant correlation with the hardness of the analyzed tree species. A similar relationship was noted between the diameter of damaged trees and their distance from beaver lodges: the diameter of trees cut by beavers decreased with an increase in distance from beaver habitats.

The increasing Canadian beaver population has caused forest damage in Finland (Härkönen, 1999). The most important type of damage was flooding (50\%) caused by the damming activity of beavers, according to own results. The trees were dead or dying in $18 \%$ of the damage areas. Prevention of beaver damage has been carried out in $80 \%$ of the damage area. In the study area (Härkönen, 1999) beaver numbers have steadily increasing, although the number of beavers taken by hunting have sharply increased too. It can suggest that the methods used to prevent beaver damages should be improved. 
In the light of legal regulations, land owners and tenants are entitled to compensation in virtue of damage caused by beavers (Art. 126, section 1, point 5 of the Nature Conservation Act of 16 April 2004; Journal of Laws 2017, item 142, as amended). However, land owners and tenants are not compensated for lost profits. It should be noted that until 2013, the State Treasury (represented by the Regional Director for Environmental Protection in the relevant matters) was liable only for losses sustained in agricultural, forest and fish farms. The above regulation was repealed on 26 July 2013 pursuant to a decision of the Constitutional Tribunal of 3 July 2013 (Journal of Laws 2013, item 842). The Constitutional Tribunal ruled that Art. 126, section 1, point 5 of the Nature Conservation Act violates the provisions of Art. 32, section 1 and Art. 64, section 2 of the Constitution in the part limiting the State Treasury's liability for beaver damage to agricultural, forest and fish farms. As a result, land owners and tenants became able to claim compensation for damage to agricultural equipment, vehicles, residential buildings, farm buildings and fencing caused by the collapse of trees cut by beavers or floods provoked by burrowing animals.

The consequences of this legal amendment are reflected in the results of this study. Beginning from 2014, the number of compensation claims for losses in hydraulic structures, livestock farms and apiaries, and the value of claims in the 'other' category increased dramatically (Table 1).

\section{Conclusions}

The analysis of the losses sustained due to the activity of the European beaver (Castor fiber) in the Region of Warmia and Mazury in North-Eastern Poland in 20092016 revealed a gradual increase in the number of damage compensation claims until 2014. The number of compensation claims relating to beaver damage decreased and stabilized after 2014. These findings could indicate that the implemented protective measures are effective. The majority of damages resulting from beavers' negative impact on the human economy were related to the flooding of grasslands, and they accounted for $50 \%$ of all beaver-induced losses. The second and third most prevalent types of damage were tree cutting and flooding of tree stands, respectively. Most claims were made in spring and summer months, which suggests that preventive measures should be undertaken mainly during that period, in particular in years characterized by low precipitation.

\section{REFERENCES}

[1] Boules, S. L., Savitzky, B. A. (2008): An Analysis of the Efficacy and Comparative Costs of Using Flow Devices to Resolve Conflicts with North American Beavers Along Roadways in the Coastal Plain of Virginia. - Timm, R. M., Madon, M. B. (eds.) Proc. $23^{\text {rd }}$ Vertebr. Pest Conf. University of California, Davis, pp. 47-52.

[2] Brzuski, P., Kulczycka, A. (1999): Beaver - Symbol of a Return to Nature. - PZŁ Publisher, Warszawa.

[3] Campbell-Palmer, R., Schwab, G., Girling, S., Lisle, S., Gow, D. (2015): Managing Wild Eurasian Beavers: a Review of European Management Practices with Consideration for Scottish Application. - Scottish Natural Heritage Commissioned Report No. 812, Inverness, UK. 
[4] Ciechanowski, M. (2010): Beaver - Environmental Engineer. How One Animal Can Affect the Ecological Diversity of the Ecosystem. - In: Frąckiel, K. (ed.) Beaver, Symbol of Return to Nature - Problems or Benefits? Osowiec Twierdza, pp. $62-79$ (in Polish).

[5] Czech, A. (2010): Beaver - a Builder and an Engineer. - Fundacja Wspierania Inicjatyw Ekologicznych, Kraków (in Polish).

[6] Czyżowski, P., Karpiński, M., Drozd, L. (2009): Forage preferences of the European Beaver (Castor fiber L.) on urban and protected areas. - Sylwan 153(6): 425-432 (in Polish).

[7] Derwich, A., Brzuski, P., Hędrzak, M. (2007): Bóbr w biotopach Bieszczadów Wysokich. - Akademia Rolnicza, Zespół Metod i Organizacji Hodowli Zwierząt Gospodarczych i Wolno Żyjących, Kraków.

[8] Derwich, A., Mróz, I. (2008): The European beaver Castor fiber L. 1758 as a factor supporting the restoration of habitats on the Upper San River. - Studia i Materiały Centrum Edukacji Przyrodniczo-Leśnej 10: 173-183 (in Polish).

[9] Gorshkov, Y., Gorshkov, D. (2011): Radiotelemetry of the Reintroduced Beavers in Volga-Kama National Nature Preserve. - In: Sjoberg, G. and Ball, J. P. (ed.) (2011): Restoring the European Beaver: 50 Years of Experience. Pensoft, Sofia-Moscow.

[10] Hartman, G. (1997): Notes on age at dispersal of beaver (Castor fiber) in an expanding population. - Canadian Journal of Zoology 75: 959-962.

[11] Härkönen, S. (1999): Forest damage caused by Canadian beaver (Castor canadensis) in South Savo, Finland. - Silva Fennica 33(4): 247-259.

[12] Hood, G. A., Manaloor, V., Dzioba, B. (2018): Mitigating infrastructure loss from beaver flooding: a cost-benefit analysis. - Human Dimensions of Wildlife Research 23(2): 146159.

[13] Janiszewski, P., Weigle, A., Gugołek, A. (2007): Stan i rozmieszczenie bobra europejskiego (Castor fiber L.) w województwie mazowieckim. - Roczniki Naukowe PTZ III 4: 367-374.

[14] Janiszewski, P., Hanzal, V. (2015): European Beaver Castor fiber - Biology and Ecology of the Species. - UWM, Olsztyn (in Polish).

[15] Janiszewski, P., Hanzal, V., Misiukiewicz, W. (2014): The European Beaver (Castor fiber) as a Keystone Species - a Literature Review. - Baltic Forestry 20(2): 277-286.

[16] Janiszewski, P., Misiukiewicz, W. (2012): European Beaver Castor fiber. - BTL Works, Warszawa (in Polish).

[17] Januszewicz, M., Misiukiewicz, W., Janiszewski, P., Folborski, J. (2018): Methodological requirements for identifying sites colonized by European beaver Castor fiber L. with the use of thermal imaging technology. - Polish Journal of Natural Science 33(1): 7-16.

[18] Kłoskowski, J. (2011): Human-wildlife conflicts at pond fisheries in eastern Poland: perceptions and management of wildlife damage. - European Journal of Wildlife Research 57: 295-304.

[19] Reynolds, P. (2000): European beaver in woodland habitats: a review. - Scottish Natural Heritage Review No 126.

[20] Statistic of Poland (2010-2017): Statistical Yearbook of the Republic of Poland. - GUS, Warszawa.

[21] Tajchman, T., Czyżowski, P., Drozd, L. (2018): Food selectivity of European beaver (Castor fiber L.) occurring in the area Lubaczów and Chotyłów forest districts. - Polish Journal of Natural Science 33(4): 533-543.

[22] Wajdzik, M., Kubacki, T., Tomek, A. (2013): Damage caused by the European beaver Castor fiber in agriculture, forestry and fisheries in Malopolska area. - Studia i Materiały CEPL w Rogowie 36(3): 131-137 (in Polish). 